\title{
SINGLE SUBJECT RESEARCH: IMPLEMENTASI PEMBELAJARAN BERBASIS MASALAH TERHADAP PEMAHAMAN MATEMATIS SISWA
}

\author{
Alfiatun Fitriani Ulfah, Rully Charitas Indra Prahmana \\ Pendidikan Matematika, Universitas Ahmad Dahlan, Yogyakarta \\ rully.indra@mpmat.uad.ac.id
}

\begin{abstract}
Abstrak
Penelitian ini bertujuan untuk mengetahui faktor-faktor kesulitan belajar siswa dan implementasi pembelajaran berbasis masalah terhadap pemahaman matematis siswa. Subjek dalam penelitian ini yaitu siswa kelas VIII A SMP Muhammadiyah 6 Yogyakarta. Teknik pengumpulan data menggunakan metode observasi dan interview untuk mengetahui faktor-faktor kesulitan belajar serta metode evaluasi untuk mengetahui kemampuan pemahaman matematis siswa. Jenis penelitian yang digunakan yaitu penelitian subjek tunggal dengan desain dasar A-B. Hasil penelitian ini menunjukkan bahwa kesulitan belajar yang dialami siswa disebabkan oleh faktor sosial yaitu dari teman satu kelas. Pembelajaran berbasis masalah mampu meningkatkan pemahaman matematis siswa. Hal ini dapat dilihat dari skor rata-rata yang diperoleh siswa sebelum diberikan treatment yaitu 28,5 dan meningkat menjadi 94 setelah diberikan treatment.
\end{abstract}

Kata kunci: Single Subject Research, Pembelajaran Berbasis Masalah, Pemahaman Matematis, Kesulitan Belajar

\begin{abstract}
This study aims to determine the factors of student's learning difficulties and the implementation of problem-based learning to student's mathematical understanding. Subjects in this study is the student of class VIII A SMP Muhammadiyah 6 Yogyakarta. The techniques of data collection used observation and interview to determine the factors of learning difficulties and evaluation methods to determine student's mathematical understanding ability. Type of research used is single subject research with basic design of A-B. The results of this study indicate that the student's learning difficulties experienced by students is caused by social factors that is from a classmate. Furthermore, problem-based learning can improve student's mathematical understanding. It can be seen from the average score obtained by the student before the treatment given that is 28.5 and increased to 94 after treatment.
\end{abstract}

Keywords: Single Subject Research, Problem-based Learning, Mathematics Understanding, learning difficulties

\section{PENDAHULUAN}

Penggunaan metode ceramah pada mata pelajaran matematika kurang efektif, sehingga pemahaman yang diperoleh kurang maksimal (Maharani, Sukestiyarno, \& Waluya, 2017; Yanti \& Prahmana, 2017; Lestari \& Prahmana, 2017; Widodo, Purnami, \& Prahmana, 2017; Kusdinar, dkk. 2017). Bunce, Flens, dan Neiles (2010) menyatakan bahwa persentase penyerapan informasi dengan cara mendengarkan (ceramah) sebesar 20\% dan seseorang dapat 
berkonsentrasi untuk menerima informasi dalam rentan waktu 10-15 menit, kemudian siswa perlu waktu 30 detik untuk berkonsentrasi menerima informasi kembali. Oleh karena itu, pembelajaran menggunakan metode ceramah belum bisa meningkatkan pemahaman siswa dalam proses pembelajaran.

Kurang maksimalnya pemahaman yang diperoleh siswa menjadi salah satu faktor penyebab kesulitan belajar. Faktor-faktor penyebab kesulitan belajar dapat berupa faktor internal (inteligensi, minat, bakat, sikap, kebutuhan, emosi, motivasi dan penyesuaian diri) dan eksternal (sekolah, guru, keluarga, dan masyarakat) (Sugihartono, dkk. 2007; Ahmadi \& Supriyono, 2004; Haryono, 2012). Ini artinya siswa akan mengalami kesulitan dalam belajar apabila tidak memiliki minat dan motivasi untuk belajar, serta didukung dengan kurangnya perhatian dari guru di sekolah.

Salah satu kesulitan belajar yang dialami siswa terdapat pada mata pelajaran matematika. Hal ini didukung oleh hasil wawancara dengan beberapa siswa, mata pelajaran matematika sering dianggap sebagai mata pelajaran yang sulit, membosankan, dan menakutkan bagi sebagian siswa. Kesulitan siswa terhadap mata pelajaran matematika pada umumnya terletak pada ketidakmampuan anak dalam membaca, berimajinasi, pemahaman konsep, kemampuan verbal, dan ketelitian siswa dalam mengerjakan soal (Rusilowati, 2006; Untari, 2013).

Siswa harus memiliki kemampuan membaca dan berimajinasi agar dapat memahami konsep-konsep matematika yang dipelajari dan mampu menggunakan konsep tersebut untuk mencari jawaban dari setiap pertanyaan yang disediakan (Sabandar, 2013). Konsep mata pelajaran matematika sendiri bukan hanya dihafal, tetapi juga membutuhkan pemahaman (Heruman, 2013). Saat siswa sudah memahami konsep materi pelajaran itu sendiri, dengan mudah siswa dapat menemukan jawaban dari setiap soal yang disediakan.

Hasil penelusuran awal ditemukan bahwa nilai UTS Kelas VII pada mata pelajaran matematika masih tergolong rendah jika dibandingkan dengan mata pelajaran yang lain. Secara umum nilai yang rendah menunjukan gejala kesulitan belajar yang dialami siswa pada mata pelajaran tersebut (Sugihartono, dkk. 2007). Berdasarkan permasalahan di atas peneliti tertarik untuk mengetahui lebih jauh terkait kesulitan siswa tersebut dalam memahami mata pelajaran matematika.

\section{METODE}

Jenis penelitian yang digunakan adalah penelitian subjek tunggal, yang bertujuan untuk menyelidiki tingkat pemahaman siswa terhadap matematika. Secara khusus penelitian ini 
dilakukan untuk mengetahui implementasi pembelajaran berbasis masalah terhadap pemahaman matematis siswa.

Pada desain penelitian subjek tunggal, pengukuran dilakukan dengan periode waktu tertentu misalnya perminggu, perhari atau perjam, perbandingan tidak dilakukan antar individu melainkan dibandingkan pada subjek yang sama dalam kondisi yang berbeda (Sunanto, dkk. 2005). Jadi dalam penelitian ini, peneliti melakukan pengukuran yang sama dan berulang-ulang untuk mempelajari berapa banyak perubahan yang terjadi pada variabel terikat (dependent) per-hari.

Kondisi disini adalah kondisi baseline dan kondisi eksperimen. Keadaan awal (baseline) merupakan pengukuran aspek dari perilaku subjek selama beberapa waktu sebelum perlakuan, sedangkan rentang waktu pengukuran untuk menetapkan baseline ini disebut fase keadaan awal (baseline phase) (Sunanto, dkk. 2005).

Dalam penelitian ini peneliti menggunakan desain A-B. Desain A-B pada dasarnya melibatkan fase baseline (A) dan fase intervensi (B). Desain A-B merupakan desain dasar dari penelitian subjek tunggal. Pada desain A-B ini tidak ada pengulangan pengukuran dimana fase baseline (A) dan intervensi (B) masing-masing dilakukan hanya sekali untuk subjek yang sama, sehingga dengan desain ini tidak dapat disimpulkan atau tidak ada jaminan bahwa perubahan pada target behavior disebabkan semata-mata oleh variabel bebas (intervensi) (Sunanto, dkk. 2005). Adapun perilaku yang diukur dalam penelitian ini adalah pembelajaran berbasis masalah terhadap tingkat pemahaman matematika, dengan kata lain penelitian ini hanya mengukur satu perilaku saja.

\section{HASIL DAN PEMBAHASAN}

\section{Hasil Penelitian}

Penelitian ini dilaksanakan di SMP Muhammadiyah 6 Yogyakarta. Berdasarkan hasil wawancara, subjek penelitian menunjukan adanya kesulitan belajar. Kesulitan belajar yang dialami siswa disebabkan oleh faktor sosial dan lingkungan yaitu dari teman satu kelas, serta faktor non sosial yaitu dari materi yang sulit.

Data ini dihasilkan dari hasil penelitian selama delapan hari, dengan pembagian 4 hari (satu hari 1 sesi selama 45 menit) yang kemudian disebut baseline, sedang-kan intervensi dilakukan selama 4 hari (satu hari 1 sesi selama 90 menit). Adapun hasil evaluasi subjek penelitian terdapat pada Tabel 1. 
Tabel 1. Skor Subjek Penelitian

\begin{tabular}{|c|c|c|}
\hline & Tanggal & SKOR \\
\hline \multirow{4}{*}{ BASELINE } & 9 Oktober 2017 & 26 \\
\hline & 11 Oktober 2017 & 30 \\
\hline & 13 Oktober 2017 & 30 \\
\hline & 16 Oktober 2017 & 28 \\
\hline \multirow{4}{*}{ INTERVENSI } & 18 Oktober 2017 & 100 \\
\hline & 20 Oktober 2017 & 90 \\
\hline & 23 Oktober 2017 & 90 \\
\hline & 25 Oktober 2017 & 100 \\
\hline
\end{tabular}

Tabel 1 merupakan tabel pengukuran skor pemahaman matematis yang dilakukan selama delapan hari. Pada kondisi baseline skor yang diperoleh subjek menunjukkan angka 26, 30, 30, 28. Pada sesi kelima atau sesi pertama kondisi intervensi skor yang dipeoleh subjek menunjukkan kenaikan yaitu 100, 90, 90, 100. Seperti terdapat pada Gambar 1.

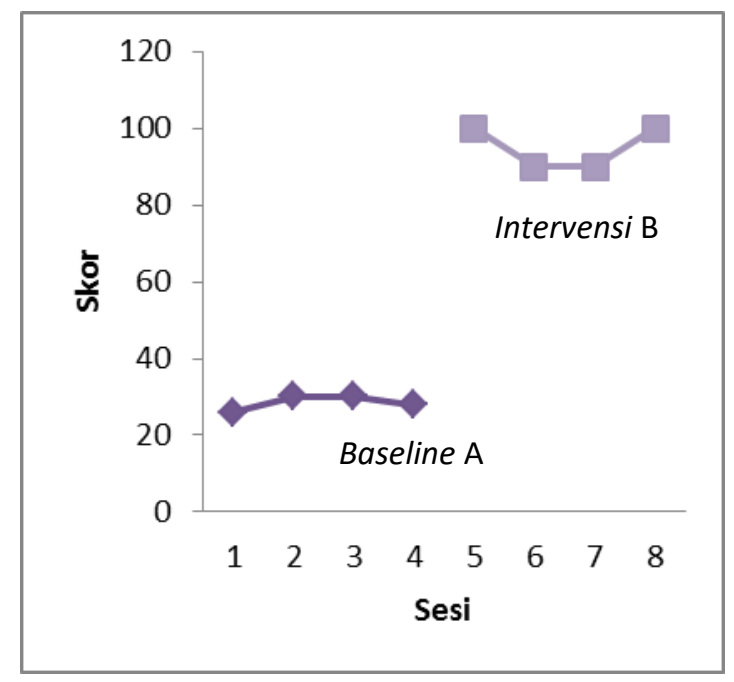

Gambar 1. Analisis visual baseline dan intervensi

1. Analisis dalam Kondisi

a. Langkah-1

Pada gambar menggunakan desain A-B, maka kondisi dapat dilihat pada Tabel 2.

Tabel 2. Kondisi Subjek

\begin{tabular}{|c|c|c|}
\hline Kondisi & $\mathrm{A} / 1$ & $\mathrm{~B} / 2$ \\
\hline
\end{tabular}


Kondisi merupakan kode dari penelitian SSR. Kode A untuk baseline sedangkan kode B untuk intervensi.

b. Langkah-2

Panjang interval dapat dilihat pada Tabel 3.

Tabel 3. Panjang Kondisi Subjek

\begin{tabular}{rrcc}
\hline & Kondisi & A/1 & B/2 \\
\hline 1. & Panjang Kondisi & 4 & 4 \\
\hline
\end{tabular}

Panjang interval ini menunjukan sesi pada setiap kondisi pada baseline A dan intervensi

B. 4 sesi untuk baseline A dan 4 sesi untuk intervensi B.

c. Langkah-3

Mengestimasi kecenderungan arah dengan menggunakan metode belah dua (splitmiddle), seperti tampak pada Gambar 2.

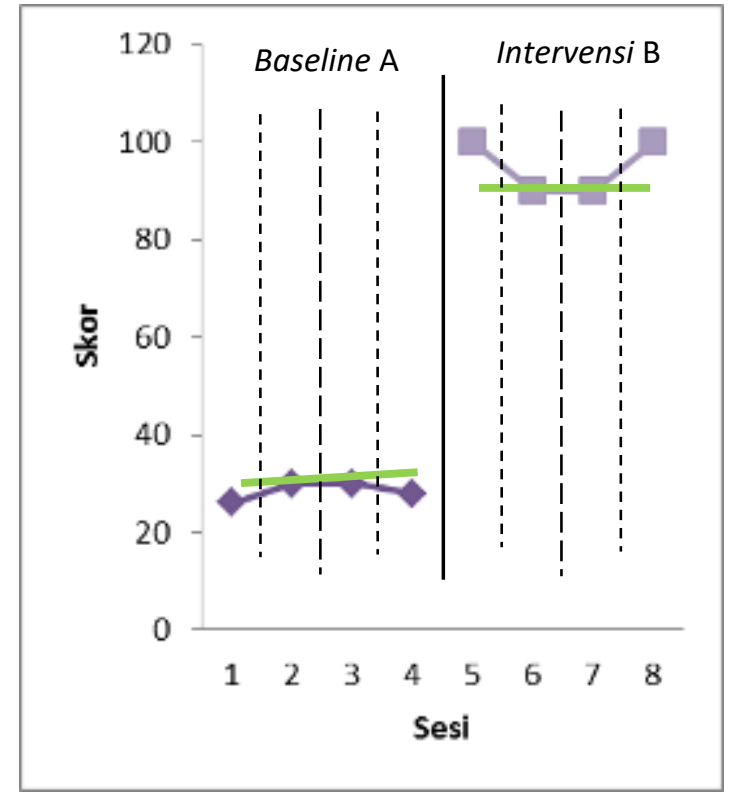

Gambar 2. Estimasi Kecenderungan Arah Subjek

Estimasi kecenderungan arah terdapat pada Tabel 4.

Tabel 4. Estimasi Kecenderungan Arah Subjek

\begin{tabular}{ccc}
\hline Kondisi & $\mathbf{A} / \mathbf{1}$ & $\mathbf{B} / \mathbf{2}$ \\
\hline 2. Estimasi Kecenderungan Arah & - & \\
\hline
\end{tabular}


d. Langkah-4

1) Baseline A

Menentukan kecenderungan stabilitas pada fase baseline $\mathrm{A}$, dalam hal ini menggunakan kriteria stabilitas $15 \%$, maka perhitungannya:

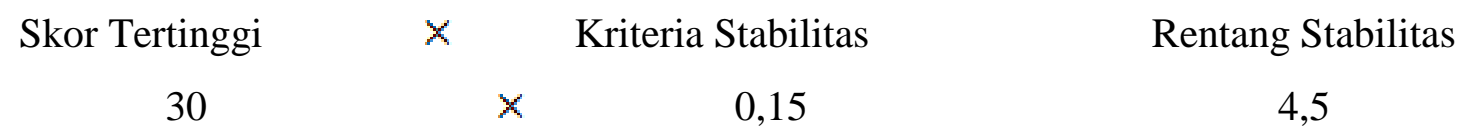

Mean level (melihat dari data baseline). Data baseline

$26+30+30+28=114$

Mean level $114 \div 4=28,5$

Menentukan batas atas

Mean level

Setengah dari rentang stabilitas

28,5

Menentukan batas bawah

Mean level

Setengah dari rentang stabilitas

28,5

2,25

26,25

Menghitung presentase data point pada kondisi baseline yang berada pada rentang stabilitas dengan cara:

Banyak data yang ada point yang ada dalam rentang

Banyaknya data point Presentase Stabilitas

Jika presentase stabilitas sebesar $85 \%-90 \%$ dikatakan stabil, sedangkan dibawah itu dikatakan tidak stabil (variable), karena hasil pehitungan untuk fase baseline adalah 75\%, maka diperoleh hasil tidak stabil (variable).

2) Intervensi $\mathrm{B}$

Menentukan kecenderungan stabilitas pada fase intervensi $\mathrm{B}$, dalam hal ini menggunakan kriteria stabilitas $15 \%$, maka perhitungannya:

Skor Tertinggi

100
Kriteria Stabilitas

0,15
Rentang Stabilitas

15

Mean level (melihat dari data intervensi). Data intervensi $100+90+90+100=380$

Mean level $380 \div 4=95$

Menentukan batas atas

Mean level

95
Setengah dari rentang stabilitas

7,5
102,5 
Menentukan batas bawah

Mean level

95
Setengah dari rentang stabilitas 7,5

Menghitung presentase data point pada kondisi intervensi yang berada pada rentang stabilitas dengan cara:

Banyak data yang ada point yang ada dalam rentang

Banyaknya data point Presentase Stabilitas

4

4

$100 \%$

Jika presentase stabilitas sebesar $85 \%-90 \%$ dikatakan stabil, sedangkan dibawah itu dikatakan tidak stabil (variable), karena hasil pehitungan untuk fase intervensi adalah $100 \%$, maka diperoleh yang stabil. Data hasil kecenderungan stabilitas terdapat pada Tabel 5.

Tabel 5. Estimasi Kecenderungan Stabilitas

\begin{tabular}{ccc}
\hline Kondisi & A/1 & B/2 \\
\hline 3. Kecenderungan Stabilitas & Variable (75\%) & Stabil (100\%) \\
\hline
\end{tabular}

\section{e. Langkah-5}

Menentukan kecenderungan jejak data, hal ini sama dengan kecenderungan arah di atas. Oleh karena itu hasil kecenderungan jejak sama dengan kecenderungan arah (Tabel 6).

Tabel 6. Kecenderungan Jejak Subjek

\begin{tabular}{ccc}
\hline Kondisi & $\mathbf{A} / \mathbf{1}$ & $\mathbf{B} / \mathbf{2}$ \\
\hline 4. Kecenderungan Jejak & + & \\
& + & $=$ \\
\hline
\end{tabular}

Dengan memperhatikan kecenderungan jejak pada Tabel 6, maka diketahui bahwa pada fase baseline arah trendnya naik ditulis (+) dan intervensi arah trendnya lurus ditulis (=) yang artinya tidak terdapat penurunan.

f. Langkah-6

Untuk menentukan level stabilitas dan rentang, sebagaimana telah dihitung di atas bahwa pada fase baseline datanya variable atau tidak stabil. Adapun rentangnya $26,25-30,75$. Pada fase intervensi datanya stabil dengan rentang $87,5-102,5$. Maka level stabilitas dan rentang-nya dapat dilihat pada Tabel 7. 
Tabel 7. Level Stabilitas dan Rentang

\begin{tabular}{|c|c|c|}
\hline Kondisi & $\mathbf{A} / \mathbf{1}$ & $B / 2$ \\
\hline \multirow{2}{*}{ 5. Level stabilitas dan rentang } & variable & stabil \\
\hline & $26,25-30,75$ & $87,5-102,5$ \\
\hline
\end{tabular}

Pada sesi kelima atau sesi pertama intervensi, skor yang diperoleh subjek lebih besar dari pada skor yang diperoleh pada sesi pertama baseline. Hal ini dikarenakan subjek belum pernah mendapatkan materi tersebut sebelumnya.

g. Langkah-7

Menentukan level perubahan dengan cara menandai data pertama dan data terakhir pada tiap fase. Hitung selisih antara kedua data dan tentukan arahnya, kemudian beri tanda $(+)$ jika membaik,(-) jika memburuk dan (=) jika tidak ada perubahan.

Baseline (A)

data besar (sesi-4)

28

Intervensi $(\mathrm{B})$

data besar (sesi-8)

100 data kecil (sesi-1)

26

data kecil (sesi-5)

100 presentase stabilitas

$$
2(+)
$$

presentase stabilitas

$$
0(=)
$$

Dengan demikian, level perubahan data dapat ditulis seperti pada Tabel 8.

Tabel 8. Level Perubahan

\begin{tabular}{ccc}
\hline Kondisi & A1 & B2 \\
\hline 6. Level perubahan & $28-26=2$ & $100-100=0$ \\
\hline
\end{tabular}

Tabel 8 menunjukan bahwa selama fase intervensi tidak terjadi perubahan, hal ini dapat dilihat dari selisih yang ditunjukan memiliki nilai nol (0). Komponen analisis dalam kondisi diatas jika dirangkum dapat dilihat pada Tabel 9.

Tabel 9. Rangkuman Hasil Analisis Visual dalam Kondisi

\begin{tabular}{lcc}
\hline \multicolumn{1}{c}{ Kondisi } & A1 & B2 \\
\hline 1. Panjang Kondisi & 3 & 5 \\
\hline 2. Estimasi Kecenderungan Arah & & \\
\hline 3. Kecenderungan Stabilitas & Variable (75\%) & Stabil (100\%) \\
\hline 4. Kecenderungan Jejak & + & $=$ \\
& & \\
\hline
\end{tabular}




\begin{tabular}{|c|c|c|}
\hline Kondisi & A1 & B2 \\
\hline \multirow{2}{*}{ 5. Level stabilitas dan rentang } & variable & stabil \\
\hline & $26,25-30,75$ & $87,5-102,5$ \\
\hline 6. Level perubahan & $28-26=2$ & $100-100=0$ \\
\hline
\end{tabular}

\section{Analisis Antar Kondisi}

Kegiatan awal untuk menganalisis antar kondisi adalah memasukan kode kondisi, yaitu kondisi 1 baseline A dengan kondisi intervensi B. Format dapat dilihat pada Tabel 10:

Tabel 10. Perbandingan Kondisi Subjek

\begin{tabular}{|c|c|}
\hline Perbandingan Kondisi & $\mathrm{B}_{1} / \mathrm{A}_{1}$ \\
& $(2: 1)$ \\
\hline
\end{tabular}

a. Langkah-1

Menentukan jumlah variabel yang diubah. Pada data rekaan variabel yang akan diubah dari kondisi baseline (A) ke intervensi (B) adalah 1. Dengan demikian pada format akan diisi seperti pada Tabel 11. Jumlah variabel yang diubah dalam penelitian ini ada 1 yaitu pemahaman matematis pada materi SPLDV.

Tabel 11. Jumlah variabel yang berubah

\begin{tabular}{lc}
\hline Perbandingan Kondisi & $\mathbf{B}_{\mathbf{1}} / \mathbf{A}_{\mathbf{1}}$ \\
& $\mathbf{( 2 : 1 )}$ \\
\hline 1. Jumlah variabel yang diubah & 1 \\
\hline
\end{tabular}

b. Langkah-2

Menentukan perubahan kecenderu-ngan arah dengan mengambil data pada analisis dalam kondisi di atas, maka dapat dilihat pada Tabel 12.

Tabel 12. Perubahan kecenderungan arah

\begin{tabular}{ccc}
\hline Perbandingan Kondisi & $\begin{array}{c}\text { B1/A1 } \\
(\mathbf{2 : 1})\end{array}$ \\
\hline 2. Perubahan kecenderungan arah dan efeknya & $=$ & - \\
& $=$ & + \\
\hline
\end{tabular}

c. Langkah-3 
Menentukan perubahan kecenderungan stabilitas. Lihat kecenderungan stabilitas pada fase baseline (A) dan intervensi (B) pada rangkuman analisis dalam kondisi seperti tampak pada Tabel 13.

Tabel 13. Perubahan kecenderungan perubahan stabilitas

\begin{tabular}{lcc}
\hline & Perbandingan Kondisi & $\mathbf{B}_{\mathbf{1}} / \mathbf{A}_{\mathbf{1}}$ \\
& & $\mathbf{( 2 : 1 )}$ \\
\hline 3. & Perubahan kecende-rungan stabilitas & Variable ke Stabil \\
\hline
\end{tabular}

Setelah diketahui bahwa kecenderu-ngan stabilitas pada fase baseline (A) tidak mencapai $85 \%-90 \%$ maka dikatakan variable. Sedang-kan pada fase intervensi (B) kecenderungan stabilitasnya $100 \%$ maka dikatakan stabil.

d. Langkah-4

Menentukan level perubahan dengan cara menentukan data point pada kondisi baseline (A) pada sesi terakhir (28) dan sesi pertama pada kondisi intervensi (B) yaitu (100) dan dihitung selisihnya $(28-100)$ maka diperoleh $(-72)$. Seperti terdapat pada Tabel 14.

Tabel 14. Perubahan level

\section{Perbandingan Kondisi}

4. Perubahan level $\quad(28-100)=(-72)$

e. Langkah-5

Menentukan overlap data pada kondisi baseline (A) dan intervensi (B) dengan cara:

1. Melihat kembali batas bawah dan atas pada kondisi baseline (A)

2. Menghitung banyak data point pada kondisi intervensi (B) yang berada pada rentang kondisi baseline (A) yaitu 0

3. Perolehan angka pada langkah (2) dibagi dengan data point dalam kondisi intervensi (B) kemudian dikalikan 100\%, maka hasilnya $(0 \div 4) \times 100 \%=0 \%$

Semakin kecil presentase overlap maka semakin baik pengaruh intervensi terhadap target behavior. Komponen antar kondisi diatas jika dirangkum dapat dilihat pada Tabel 15 .

Tabel 15. Rangkuman hasil analisis visual antar kondisi

\section{Perbandingan Kondisi}

\section{$\mathbf{B}_{1} / \mathbf{A}_{1}$}

$(2: 1)$

1. Jumlah variabel yang diubah

1


Perbandingan Kondisi

$\mathbf{B}_{1} / \mathbf{A}_{1}$

$(2: 1)$

2. Perubahan kecenderungan arah dan efeknya

$$
=\quad+
$$

3. Perubahan kecenderungan stabilitas

Variable ke Stabil

4. Perubahan level

$(28-100)=(-72)$

\section{Presentase Overlap}

$0 \%$

\section{Pembahasan}

Hasil penelitian ini menunjukkan bahwa kesulitan belajar yang dialami siswa disebabkan oleh faktor sosial dan lingkungan yaitu dari teman satu kelas, serta faktor non sosial yaitu dari materi yang sulit. Hal ini didukung oleh pendapat sejumlah ahli yang menyatakan bahwa kesulitan belajar dapat disebabkan oleh faktor fisiologis, psikologis, faktor sosial, faktor non sosial, serta lingkungan (Irham \& Wiyani, 2013; Sugihartono, dkk. 2007; Ahmadi \& Supriyono, 2012). Oleh karena itu, hasil penelitian ini mendukung sejumlah hasil penelitian sebelumnya (Irham \& Wiyani, 2013; Ahmadi \& Supriyono, 2012; Sugihartono, dkk. 2007).

Penerapan pembelajaran berbasis masalah yang telah dilaksanakan dalam penelitian ini adalah pembelajaran pada materi sistem persamaan linear dua variable (SPLDV). Pada fase baseline, tiap sesi siswa diminta untuk mengerjakan soal guna mengukur kemampuan awal siswa terhadap materi tersebut. Pada fase ini, siswa belum bisa mengalikan dua persamaan tersebut, hal ini dapat dilihat pada Gambar 3.

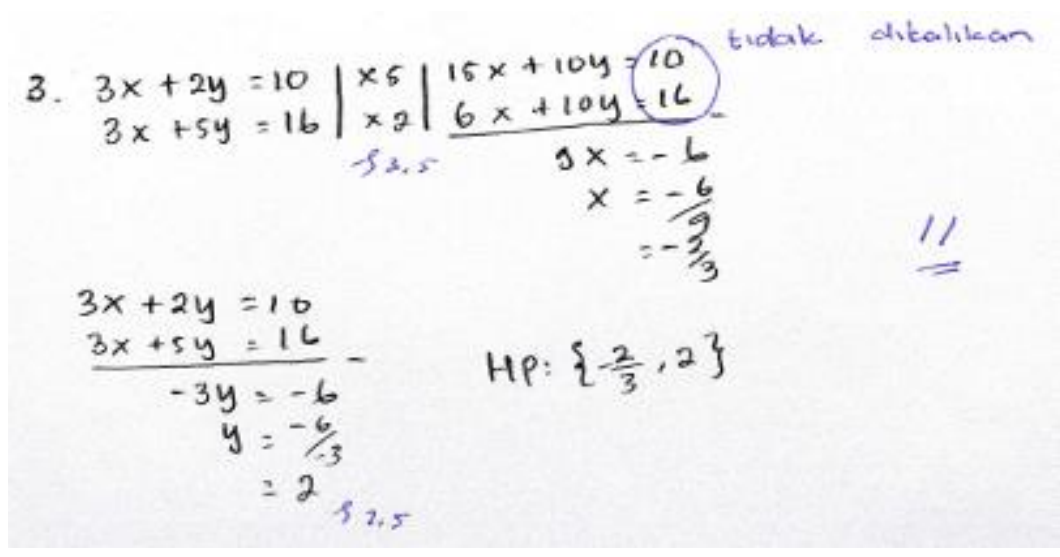

Gambar 3. Lembar Jawab Baseline

Kemudian pada fase intervensi, tiap sesi siswa diminta mengajukan pertanyaan dari soal-soal yang sudah dikerjakan sebelumnya kemudian mendiskusikan masalah tersebut 
dengan peneliti. Setelah masalah terpecahkan, siswa diminta mengerjakan soal lagi untuk mengukur kemampuan siswa. Pada sesi ini siswa sudah bisa mengerjakan soal sistem persamaan linear dua variabel, hal tersebut dapat dilihat pada Gambar 5.

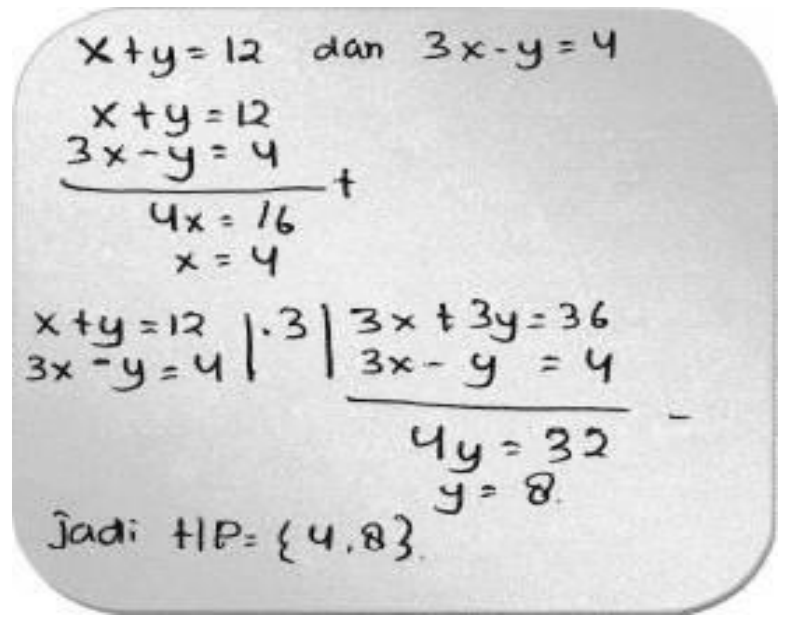

Gambar 5. Lembar Jawab Intervensi

Hasil ini sesuai dengan sejumlah hasil penelitian yang menyatakan bahwa pembelajaran berbasis masalah adalah pendekatan pembelajaran yang berpusat pada siswa yang berdasar pada analisis, resolusi, dan diskusi terhadap masalah yang diberikan (Cazorla, 2008; Ananggih, dkk, 2017). Masalah yang diberikan yaitu penyelesaian sistem persamaan linear dua variabel dengan cara substitusi, eliminasi, gabungan (eliminasi dan substitusi), grafik serta penyelesaian soal cerita.

Berdasarkan hasil penelitian, pembelajaran berbasis masalah efektif untuk meningkatkan kemampuan pemahaman matematis siswa. Hal ini sejalan dengan penelitian sebelumnya (Ananggih, dkk. 2017; Maharani, Sukestiyarno, \& Waluya, 2017; Yanti \& Prahmana, 2017; Widodo, Purnami, \& Prahmana, 2017; Kharida, dkk. 2009; Lestari \& Prahmana, 2017; Herman, 2007; Widodo, Purnami, \& Prahmana, 2017; Kusdinar, dkk. 2017), sehingga memberikan kontribusi sebagai penegasan tentang implementasi pembelajaran berbasis masalah terhadap pemahaman matematis siswa.

\section{SIMPULAN}

Berdasarkan hasil dan pembahasan dapat diambil simpulan bahwa kesulitan belajar yang dialami siswa disebabkan oleh faktor sosial yaitu dari teman satu kelas serta faktor non sosial yaitu karena materinya yang sulit. Selanjutnya, kemampuan pemahaman matematis siswa sebelum diberikan treatment berada pada rata-rata skor 28,5 dengan skala 100 . Treatment yang diberikan berupa pembelajaran berbasis masalah. Setelah subjek diberikan 
treatment, pemahaman matematis siswa meningkat, ditunjukkan dari rata-rata skor setelah diberikan treatment yaitu 95 dengan skala 100. Hal ini menunjukkan bahwa pembelajaran berbasis masalah mampu meningkatkan pemahaman matematis siswa

\section{DAFTAR PUSTAKA}

Ahmadi, A., \& Widodo, S. (2004). Psikologi Belajar. Jakarta: Rineka Cipta.

Ananggih, G.W., Yuwono, I., \& Sulandra, I.M. (2017). Pembelajaran Berbasis Masalah untuk Meningkatkan Pemahaman Matematika Siswa Kelas IX SMP. Jurnal Kajian Pembelajaran Matematika, 1(1), 25-35.

Bunce, D. M., Flens, E. A., \& Neiles, K. Y. (2010). How long can students pay attention in class? A study of student attention decline using clickers. Journal of Chemical Education, 87(12), 1438-1443.

Cazzola, M. (2008). Problem-Based Learning and Mathematics: possible synergical actions. ICERI2008 Proceeding, IATED (International Association of Technology, Education and Development), Valencia, Spain.

Haryono. (2012). Diagnosis Kesulitan Belajar Matematika Siswa Kelas V SD Negeri Gambiran Yogyakarta Tahun Pelajaran 2011/2012. Skripsi. Yogyakarta: Universitas Ahmad Dahlan.

Herman, T. (2007). Pembelajaran Berbasis Masalah untuk Meningkatkan untuk Meningkatkan Kemampuan Berpikir Matematis Tingkat Tinggi Siswa Sekolah Menengah Pertama. Jurnal Educa Tionist, 1(1), 47-56.

Heruman. (2013). Model Pembelajaran Matematika. Bandung: PT Remaja Rosdakarya.

Irham, M., \& Wiyani, N.A. (2013). Psikologi Pendidikan Teori dan Apikasi dalam Proses Pembelajaran. Yogyakarta: Ar-Ruzz Media.

Khairani, M. (2014). Psikologi Belajar. Yogyakarta: Aswaja Pressindo.

Kharida, L.A., Rusilowati, A., \& Pratikyo, K. (2009). Penerapan Model Pembelajaran Berbasis Masalah untuk Peningkatan Hasil Belajar Siswa pada Pokok Bahasan Elastisitas Bahan. Jurnal Pendidikan Fisika, 5(1), 83-89.

Kusdinar, U., Sukestiyarno, S., Isnarto, I., \& Istiandaru, A. (2017). Krulik and Rudnik Model Heuristic Strategy in Mathematics Problem Solving. International Journal on Emerging Mathematics Education, 1(2), 205-210.

Lestari, R. M., \& Prahmana, R. C. I. (2017). Model guided inquiry, student teams achievement division, dan kemampuan penalaran matematis siswa. Beta Jurnal Tadris Matematika, 10(2), 153-165.

Maharani, H. R., Sukestiyarno, S., \& Waluya, B. (2017). Creative thinking process based on wallas model in solving mathematics problem. International Journal on Emerging Mathematics Education, 1(2), 177-184.

Rusilowati, A. (2006). Profil Kesulitan Belajar Fisika Pokok Bahasan Kelistrikan Siswa SMA Di Kota Semarang. Jurnal Pendidikan Fisika Indonesia, 4(2), 100-106.

Sabandar, J. (2013). Berpikir Reflektif dalam Pembelajaran Matematika. Tersedia di website: http://file. upi. edu/Direktori/FPMIPA/JUR._PEND._MATEMATIKA/ 194705241981031-JOZUA_SABANDAR/KUMPULAN_MAKALAH_DAN_JURNAL/

Berpikir_Reflektif2.pdf.(diakses tanggal 25 Mei 2013).

Sugihartono, dkk. (2007). Psikologi Pendidikan. Yogyakarta: UNY Press.

Sunanto, J., Takeuchi, K., \& Nakata, H. (2005). Pengantar Penelitian Dengan Subjek Tunggal. Center for Research on International Cooperation in Education Development (CRICED) University of Tsukuba. 
Untari, E. (2013). Diagnosis Kesulitan Belajar Pokok Bahasan Pecahan Pada Siswa Kelas V Sekolah Dasar. Jurnal Ilmiah STKIP PGRI Ngawi, 13(1), 1-8.

Widodo, S. A., Purnami, A. S., \& Prahmana, R. C. I. (2017). Team accelerated instruction, initials and problem-solves ability in junior high school. International Journal on Emerging Mathematics Education, 1(2), 193-204.

Yanti, O. F., \& Prahmana, R. C. I. (2017). Model Problem Based Learning, Guided Inquiry, dan Kemampuan Berpikir Kritis Matematis. JRPM (Jurnal Review Pembelajaran Matematika), 2(2), 120-130.

Yasri, H.T. (2014). Efektivitas Terapi Sensori Integrasi terhadap Penurunan Perilaku Hiperaktif Anak ADHD (Attention Deficit Hyperactive Disorder) di Pusat Terapi Fajar Mulia Ponorogo. Skripsi. Malang: Universitas Islam Negeri Maulana Malik Ibrahim. 